\title{
Estimating Twig and Foliage Biomass of Sagebrush, Bitterbrush, and Rabbitbrush in the Great Basin
}

\author{
SHEILA DEAN, J. WAYNE BURKHARDT, AND RICHARD O. MEEUWIG
}

\begin{abstract}
Shrub crown characteristics useful in regression equations for predicting two biomass components (annual production and fine fuels) were identified for six shrubs common to the Great Basin. Shrub characteristics most useful in these equations were maximum and minimum crown diameter, and crown denseness and depth. Prediction equations were developed for each species or subspecies included in this study. Additionally, biomass equations were developed for combined species or subspecies of morphological similarity within the Artemisia genus.
\end{abstract}

As early as 1958, Evans and Jones addressed the practical importance of a method for determining forage production in which clipping or mowing was not necessary. Since then, much attention has been directed toward developing methods for predicting shrub production from easily measured crown dimensions. Volumetric or crown area relationships based on crown height and diameters have been described for serviceberry (Amelanchier alnifolia) by Lyon (1968), for eight Chihuahuan desert shrubs by Ludwig et al. (1975), and for big sagebrush (Artemisia tridentata wyomingensis) by Rittenhouse and Sneva (1977). Brown and Marsden (1976) and Alexander (1978) developed equations for predicting fuel loadings from height and percent crown cover measurements. Va rious stem diameter measurements were used as biomass predictors by Ohmann et al. (1976), Brown (1976), and Grigal and Ohmann (1977). Davis et al. (1972) related forage production to ring widths for several salt desert shrub species. Thus, the value and practicality of such methods has been well documented.

The sagebrush taxon, Artemisia, constitutes the most abundant and widespread shrub component of ecosystems in the Great Basin and provides a source of food and cover for livestock and wildlife. Taxonomic difficulties exist within this genus at the species, subspecies, and variety levels. Although ecological differences have been described (Winward and Tisdale 1977), field identification of sagebrush species is often difficult to determine. This is especially true between low and black sagebrush ( $A$. arbuscula and $A$. nova) and the subspecies differentiations for big sagebrush $(A$. tridentata ssp. tridentata, $A$. tridentata spp. vaseyana, and $A$. tridentata spp. wyomingensis). A reliable dimension analysis technique for determining canopy biomass components in which species differences were not necessary would expedite field data collection and data analysis procedures.

The primary objective of this study was to identify shrub crown characteristics which could be used to predict two shrub biomass components (annual production and fine fuels) and to formulate reliable prediction equations from these characteristics. The secon-

Authors are research assistant and assistant professor, Renewable Natural Resources Division, University of Nevada Reno, 1000 Valley Road, Reno, Nevada 89512; and research forester, Intermountain Forest and Range Experiment Station, Renewable Natural Resources Center, 920 Valley Road, Reno, Nevada 89512

This research represents the contributions of the Nevada Agricultural Experiment Station Journal Series Number 446. Financial support from the Intermountain Forest and Range Experiment Station is acknowledged. dary objective was to evaluate the reliability of the prediction equations when shrub species of similar form were grouped together.

\section{Methods and Procedures}

Fifty-nine study sites were selected to represent the major shrub communities associated with the pinyon-juniper vegetation in the Great Basin. The study included the following taxa and number of sample shrubs:

Artemisia tridentata tridentata $\quad(\mathrm{n}=10)$ ARTRTR Basin big sagebrush

Artemisia tridentata vaseyana $\quad(n=54)$ ARTRVA Mountain big sagebrush

Artemisia tridentata wyomingensis $\quad(n=50)$ ARTRWY Wyoming big sagcbrush

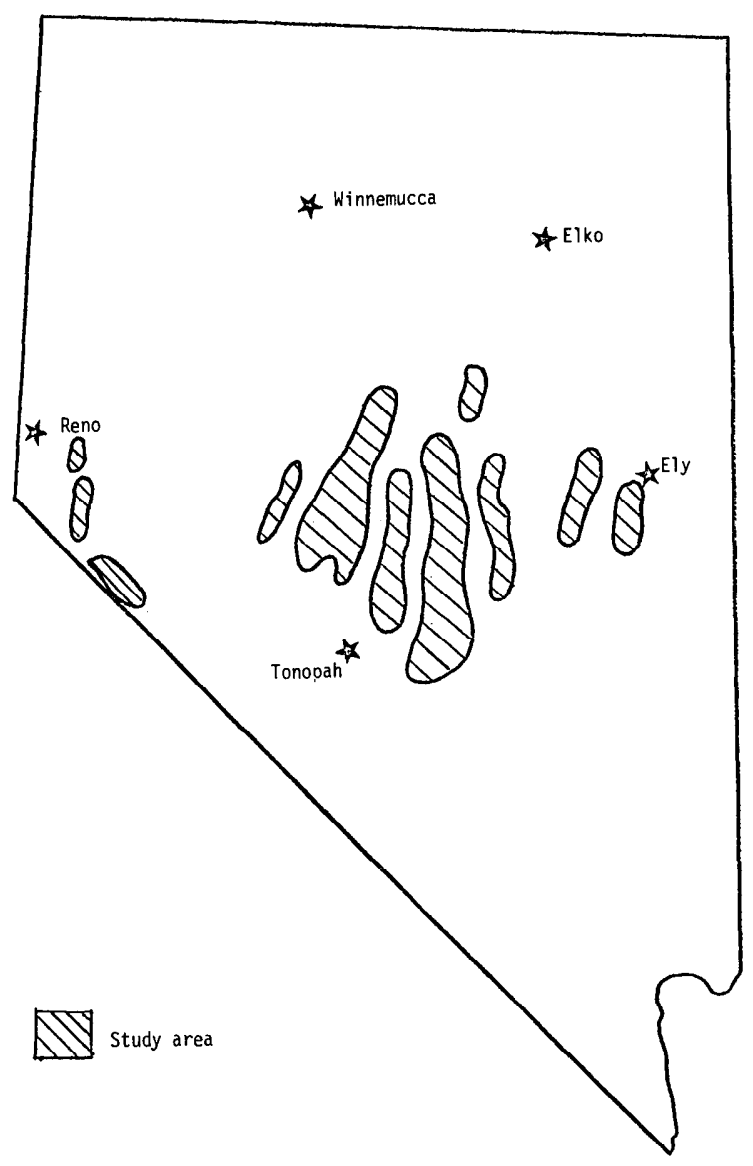

Fig. 1. Study areas. 
Purshia tridentata

Chrysothamnus viscidiflorus

$(n=49)$ PUTR

$(n=50)$ CHVI
Low sagebrush

Black sage-

brush

Bitterbrush

Green rabbitbrush

Basin big sagebrush occurs within the pinyon-juniper types in the Great Basin but only as a minor component. For this reason it was not intensively sampled $(n=10)$. All study sites are located in Nevada and represent variations in elevation, aspect, and topoedaphic conditions. General locations of these study sites are shown in Figure 1.

Sampling occurred from June through October of 1978. Sample shrubs were randomly selected so as to represent size and form variations at each site by means of line intersection. With this method, every second or third shrub intersecting a 100 -foot steel tape became a sample unit. An average of five shrubs were sampled per study site. For each shrub sampled, the following measurements werc recorded:

Shrub height $(\mathrm{H})$ - The vertical distance $(\mathrm{cm})$ from ground level to the highest perennial portion of the shrub.

Crown depth (CD) - The vertical measurement $(\mathrm{cm})$ of the foliated portion of the shrub crown.

Maximum diameter (MX) - The horizontal distance $(\mathrm{cm})$ along the widest axis of the shrub crown.

Minimum diameter $(\mathrm{MN})$ - The horizontal distance $(\mathrm{cm})$ along the narrowest axis of the shrub crown.

Crown denseness (D) - The ocular estimated percent of foliage within the shrub crown.

Number of basal stems (NS) - The number of supportive, live stems at ground level.

Basal stem diameter (SD)- The root crown diameter $(\mathrm{cm})$ at ground level.

The ocular estimates of crown denseness were compared to crown denseness ratings obtained by point sampling within a shrub crown. Forty percent of the sample shrubs in this study (two out of five at each site) were point sampled after the ocular estimate of crown denseness had been made. For the purpose of point sampling, crown denseness was defined as the percent of points within the crown which intercepted foliage. Sampling occurred along the maximum and minimum diameter of the shrub crown using a frame with points $2.5 \mathrm{~cm}$ apart. Sampling intensity varied with shrub size and averaged 40 points per shrub crown. The crown denseness estimates from point sampling were compared to the ocular estimates by means of a $T$-test.

The shrubs were then cut down at ground level and the number of growth rings were recorded when determinable. At this point, all twigs, live and dead, were clipped at a $6 \mathrm{~mm}$ diameter and placed in paper bags for return to the laboratory.

The samples were oven-dried at $100^{\circ} \mathrm{C}$ for a 24-hour period. Following drying, the twigs and leaves in each sample were separated into two biomass components. The first consisted of all twigs $6 \mathrm{~mm}$ or less in diameter plus all leaves. This component represented the fine fuel biomass of the sample shrub as used by the U.S. Forest Service (Demming et al. 1978). Secondly, live twigs $3 \mathrm{~mm}$ or less in diameter and all leaves were separated from the sample and weighed. This size fraction was used as an objective approximation of the annual production of the sample shrub.

The $0-6 \mathrm{~mm}$ and $0-3 \mathrm{~mm}$ oven-dried weights $(\mathrm{g})$ became the dependent variables in forward step-wise regression analyses to identify those independent crown measurements that are helpful in predicting the fine fuel and annual biomass components, respectively. All analyses were conducted at the $\propto=.05$ significance level. The inclusion of variables into a model was terminated at the point where the beta coefficient became insignificant in the equation. The following four general models were evaluated:

\section{Model I}

$\mathrm{x}, \mathrm{y}$
Model III

$\mathrm{x}, \ln (\mathrm{y})$
Model IV

$\ln (x), \ln (y)$ where $\mathrm{x}$ represents the independent variables and $\mathrm{y}$ represents the dependent variables. Scatter diagrams for all independent/dependent variable combinations were initially constructed to analyze their linear relationships and to aid in the construction of an appropriate regression model.

\section{Results and Discussion}

The criteria for evaluation of the various regression models were the coefficient of determination $\left(R^{2}\right)$, which measures the linear strength of a function, and the standard error of the estimate $(S y . x)$, which in $\log -\log$ models very closely approximates the coefficient of variation. In all cases, model IV $(\ln (x), \ln (y))$ performed the best on the basis of our selection criterion. Prediction equations with their associated $R^{2}$ and standard error terms are given in Table 1. Reliable equations resulted from the $\log -\log$ model with $R^{2}$ 's ranging from .81 for the fine fuel equation for green rabbitbrush to .95 for the fine fuel equation for low sagebrush. Except for rabbitbrush, the fuel component equations were consistently better than the annual production equations with higher $R^{2}$ values and lower Sy.x.

Excluding the fine fuel equation for rabbitbrush $(S y \cdot x=.45)$, the standard errors were reasonably low, ranging from .22 for the fine fuel equation for low sagebrush to .38 for the annual production equation for black sagebrush and Wyoming big sagebrush. Maximum and minimum diameters and crown depth and denseness were the variables most often used in the equations.

Due to similarities in growth form within the sagebrush complex it is often difficult to distinguish between different sagebrush species and varieties on the basis of morphology alone. These distinctions become even more difficult in ecotones where the transition of one Artemisia species or variety to another occurs. Dissension even occurs among taxonomists in regard to the number of subdivisions and taxonomic ranks for the Artemisia taxon (Winward and Tisdale 1977). For these reasons, it would be desirable to formulate prediction equations for which these species distinctions would not be necessary. Based on the assumption that standing biomass is a function of crown size and denseness rather than shrub species, which is a function of site characteristics, this should be possiblc. When the data for the various species and subspecies of sagebrush were combined and analyzed (Arar + Arno; Artrva + Artrwy + Artrtr; total Artemisia spp.), the new equations resulted in negligible losses in prediction reliability with regard to the $R^{2}$ and $S y . x$. These equations and their associated $R^{2}$ and $S y . x$ are given in Table 2 for comparison with individual species equations (Table 1). Essentially, the same variables (maximum and minimum diameters, crown depth and denseness) were important. $R^{2}$ 's range from .85 for the annual production component for the big sage complex and the combination of all sagebrush to .94 for the fine fuel component for the low sage-black sage combination.

The ccological differences between sagebrush vegetation types are important to recognize in terms of analyzing site potentials and conditions. For these reasons sagebrush species and sub-species differentiations should be made as accurately as possible. However, in cases where biomass determination is desired, the combination equations would be useful. Shrub identification to genus alone expedites this kind of data collection and eliminates identification error by inexperienced field crews. This, in turn, results in easier analysis and more accurate results.

The comparison of the crown estimate data with the point sampled density data revealed that the means of the two data sets were not significantly different $(\propto=.01)$. This indicates that the point sampling procedure served as a successful technique for calibrating ocular estimates and resulted in consistent estimation of the crown denseness. The calibration of ocular estimates is important to minimize inconsistencies of density estimates made by an individual over a period of time or between different estimators. Consistency of density estimates is more important than accuracy. The point sampling technique serves this calibration function. 
Table 1. Fine fuel and annual production prediction equations for five shrub species.

\begin{tabular}{|c|c|c|}
\hline Species equations & $R^{2}$ & $S y \cdot x$ \\
\hline $\begin{array}{l}\text { Artemisia arbuscula }(50 \text { observations }) \\
\text { In }(\text { FUEL })=-4.04+1.07(\ln (\mathrm{MX}))+.82(\ln (\mathrm{MN}))+.30(\ln (\mathrm{D}))+.24(\ln (\mathrm{SD}))^{1} \\
\operatorname{Ln}(\mathrm{BIOM})=-4.22+.94(\ln (\mathrm{MN}))+.60(\ln (\mathrm{MX}))+.47(\ln (\mathrm{D}))+.29(\ln (\mathrm{SD}))\end{array}$ & $\begin{array}{l}.95 \\
.93\end{array}$ & $\begin{array}{l}.22 \\
.27\end{array}$ \\
\hline $\begin{array}{l}\text { Artemisia nova }(50 \text { observations) } \\
\ln (\mathrm{FUEL})=-3.77+.68(\ln (\mathrm{MX}))+.53(\ln (\mathrm{MN}))+.69(\ln (\mathrm{CD}))+.41(\ln (\mathrm{SD}))+.23(\ln (\mathrm{D})) \\
\ln (\mathrm{BIOM})=-5.75+.21(\ln (\mathrm{MX}))+.86(\ln (\mathrm{D}))+.58(\ln (\mathrm{MN}))+.72(\ln (\mathrm{SD}))+.55(\ln (\mathrm{CD}))\end{array}$ & $\begin{array}{l}.93 \\
.83\end{array}$ & $\begin{array}{l}.24 \\
.38\end{array}$ \\
\hline $\begin{array}{l}\text { Artemisia tridentata vaseyana }(54 \text { observations) } \\
\ln (\mathrm{FUEL})=-4.94+.63(\ln (\mathrm{MX}))+.59(\ln (\mathrm{MN}))+.39(\ln (\mathrm{CD}))+.42(\ln (\mathrm{SD}))+.41(\ln (\mathrm{D}))+.33(\ln (\mathrm{H})) \\
\ln (\mathrm{BIOM})=-6.34+.82(\ln (\mathrm{MN}))+.76(\ln (\mathrm{MX}))+.70(\ln (\mathrm{D}))+.42(\ln (\mathrm{CD}))\end{array}$ & $\begin{array}{l}.92 \\
.85\end{array}$ & $\begin{array}{l}.25 \\
.32\end{array}$ \\
\hline $\begin{array}{l}\text { Artemisia tridentata wyomingensis }(50 \text { observations) } \\
\ln (\mathrm{FUEL})=-4.45+1.25(\ln (\mathrm{MX}))+.59(\ln (\mathrm{MN}))+.35(\ln (\mathrm{H}))+.22(\ln (\mathrm{D})) \\
\ln (\mathrm{BIOM})=-8.79+1.16(\ln (\mathrm{MX}))+1.05(\ln (\mathrm{D}))+.65(\ln (\mathrm{CD}))+. .39(\ln (\mathrm{MN}))\end{array}$ & $\begin{array}{l}.89 \\
.86\end{array}$ & $\begin{array}{l}.28 \\
.38\end{array}$ \\
\hline $\begin{array}{l}\text { Purshia tridentata }(49 \text { observations) } \\
\ln (\mathrm{FUEL})=-6.12+1.24(\ln (\mathrm{MX}))+.30(\ln (\mathrm{SD}))+.47(\ln (\mathrm{D}))+.53(\ln (\mathrm{CD}))+.41(\ln (\mathrm{MN})) \\
\ln (\mathrm{BIOM})=-7.40+1.49(\ln (\mathrm{MX})+.74(\ln (\mathrm{D}))+1.28(\ln (\mathrm{CD}))+.64(\ln (\mathrm{H}))\end{array}$ & $\begin{array}{l}.91 \\
.84\end{array}$ & $\begin{array}{l}.34 \\
.37\end{array}$ \\
\hline $\begin{array}{l}\text { Chrysothamnus viscidiflorus (50 observations) } \\
\ln (\text { FUEL })=-4.47+.99(\ln (\mathrm{MN}))+.87(\ln (\mathrm{MX}))+.60(\ln (\mathrm{D})) \\
\ln (\mathrm{BIOM})=-6.45+.79(\ln (\mathrm{MN}))+.83(\ln (\mathrm{MX}))+.69(\ln (\mathrm{D}))+.41(\ln (\mathrm{CD}))\end{array}$ & $\begin{array}{l}.81 \\
.86\end{array}$ & $\begin{array}{l}.45 \\
.33\end{array}$ \\
\hline
\end{tabular}

\begin{tabular}{llc}
\hline 'Equation abbreviations: & MX - maximum diameter $(\mathrm{cm})$ & D - crown denseness (\%) \\
& MN - minimum diameter (cm) & SD - basal stem diameter (cm) \\
H - shrub height $(\mathrm{cm})$ & FUEL - up to 6mm diameter twigs (weight - g) \\
& NS - number of basal stems & BIOM - up to 3mm diameter twigs (weight - g) \\
& CD - crown depth $(\mathrm{cm})$ &
\end{tabular}

The concept of an objective, definitive point for separating annual production has practical implications in terms of consistency in sampling. Annual twig production is not easily recognized for all species, especially as the growing season progresses. The $3 \mathrm{~mm}$ twig diameter component used in this study was an objective approximation of the average annual biomass produced by the sample shrubs. It was apparent that this size class did in fact closely approximate the 1978 twig and foliage production for bitterbrush and sagebrush. However, this is an area which deserves further research.

In contrast to sagebrush and bitterbrush, the $3 \mathrm{~mm}$ twig diameter did not appear to be a meaningful separation point for the current production of rabbitbrush. In the study area, green rabbitbrush produces a multitude of stems, most of which are less than $3 \mathrm{~mm}$ in diameter at the root crown. Over-winter observation of rabbitbrush reveals that these stems a re perennial and are not the result of one-year's growth. Because the majority of the sample twigs fell into the $0-3 \mathrm{~mm}$ size class, there was little difference in the weights of the two biomass components. This accounts for the simila rity of the prediction equations for the two biomass classes of rabbitbrush. The twig diameter increment for annual production is not known and is probably less consistent than that for bitterbrush and sagebrush.

There are certain inherent problems with sampling for shrub biomass over a 3 to 4 month period. However, such a duration is sometimes unavoidable and necessary to obtain adequate sample sizes. Problems arise with plant phenology and desiccation. Sampling early within the growing season may produce underestimates of the annual production increment in that production is still incomplete. On the other hand, sampling late in the field season can also result in underestimates of the annual production due to desiccation and leaf losses from summer drought. The sampling in this study was first conducted at the lower elevations and on the earlier vegetation types (Artrwy, Arno). With later sampling it became more important to catch leaves that fell off during the sampling procedure. Although sampling at both times resulted in

Table 2. Fine fuel and annual production prediction equations for various combinations of sagebrush species.

\begin{tabular}{lc}
\hline \hline \multicolumn{1}{c}{ Species equations } & $R^{2}$ \\
\hline Artemisia arbuscula and $A$. nova $(100$ observations $)$ & .94 \\
$\ln (\mathrm{FUEL})=-3.96+.95(\ln (\mathrm{MX}))+.62(\ln (\mathrm{MN}))+.37(\ln (\mathrm{CD}))+.26(\ln (\mathrm{SD}))+.26[\ln (\mathrm{D})]^{1}$ & .94 \\
$\ln (\mathrm{BIOM})=-5.14+.72(\ln (\mathrm{MN}))+.51(\ln (\mathrm{SD}))+.77(\ln (\mathrm{D}))+.60(\ln (\mathrm{MX}))$ & .86 \\
Artemisia tridentata tridentata, vaseyana, and wyomingensis $(114$ observations) & .35 \\
$\ln (\mathrm{FUEL})=-4.11+.84(\ln (\mathrm{MX}))+.61(\ln (\mathrm{MN}))+.50(\ln (\mathrm{CD}))+.28(\ln (\mathrm{SD}))$ & .90 \\
$\ln (\mathrm{BIOM})=-8.24+.92(\ln (\mathrm{MX}))+1.0(\ln (\mathrm{D}))+.65(\ln (\mathrm{MN}))+.58(\ln (\mathrm{CD}))$ & .85 \\
Total Artemisia's $(214$ observations) & .29 \\
In (FUEL) $=-3.86+.88(\ln (\mathrm{MX}))+.64(\ln (\mathrm{MN})+.37(\ln (\mathrm{CD}))+.27(\ln (\mathrm{D}))+.28(\ln (\mathrm{SD}))$ & .36 \\
$\ln (\mathrm{BIOM})=-6.70+.66(\ln (\mathrm{MN}))+.69(\ln (\mathrm{MX}))+.87(\ln (\mathrm{D}))+.47(\ln (\mathrm{CD}))+.11(\ln (\mathrm{NS}))+.15(\ln (\mathrm{SD}))$ & .85 \\
\hline
\end{tabular}

\begin{tabular}{ll}
\hline Equation abbreviations: & MX - maximum diameter $(\mathrm{cm})$ \\
MN - minimum diameter $(\mathrm{cm})$ \\
$\mathrm{H}-$ shrub height $(\mathrm{cm})$ \\
NS - number of basal stems \\
CD - crown depth $(\mathrm{cm})$ \\
D - crown denseness $(\%)$ \\
SD - basal stem diameter $(\mathrm{cm})$ \\
FUEL - up to $6 \mathrm{~mm}$ diameter twigs (weight - g) \\
BIOM - up to 3mm diameter twigs (weight - g)
\end{tabular}


underestimates, hopefully the sampling error was consistent. Foresight into sampling error can result in more accurate and reliable data.

\section{Conclusions}

Based on the $R^{2}$ and $S y \cdot x$ values for the prediction equations, it appears that fine fuel and annual biomass can indeed be predicted from shrub crown measurements. Maximum and minimum diameters and crown depth and denseness were the shrub characteristics most useful in biomass prediction. These are also easily measured variables and are generally well defined. However, it is necessary to calibrate ocular density estimates with some form of point sampling.

Species differentiation within the Artemisia taxon in the Great Basin is not necessary for biomass prediction purposes. Shrub biomass apparently is more a function of crown size and denseness than species differences. Depending upon the objective of biomass sampling and the capabilities of survey crews, sagebrush biomass can be adequately predicted either on the basis of individual species equations or with the appropriate combination equation.

The $3 \mathrm{~mm}$ diameter increment is a feasible, definitive break for separating the annual production biomass component for all sagebrush and bitterbrush in the Great Basin. This determination point for rabbitbrush is less consistent and probably smaller than $3 \mathrm{~mm}$.

\section{Literature Cited}

Alexander, Martin E. 1978. Estimating fuel weights of two common shrubs in Colorado lodgepole pine stands. U.S. Dep. Agr. Forest Serv. Res. Note RM-354, 4 p. Rocky Mt. Forest and Range Exp. Sta., Fort Collins, Colo.

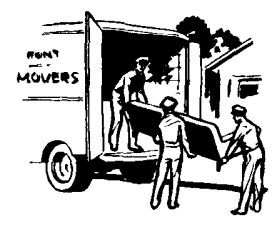

CHANGE OF ADDRESS notices should be sent to the Managing Editor, 2760 West Fifth Ave., Denver, Colo. 80204, no later than the first day of the month of issue. Copies lost due to change of address cannot be replaced unless adequate notice is given. To assure uninterrupted service, provide your local postmaster with a Change of Address Order (POD Form 3575) indicating thereon to guarantee forwarding postage for second-class mail.

\section{Masters Theses Recently Completed}

\section{Montana State University}

(1) Plant succession on five naturally revegetated stripmined deposits at Colstrip, Mt. by C.L. Skilbred. 1979. $128 \mathrm{p}$.

(2) Effects of topsoiling and other reclamation practices on nonseeded species establishment on surface mined land at Colstrip, Mt. by L.A. King. 1980.129 p.

(3) Effects of prescribed burning on mixed prairie vegetation in southeastern Montana. by R.B. Rennick. 1981. $144 \mathrm{p}$.
Brown, James K. 1976. Estimating shrub biomass from basal stem diameters. Can. J. Forest Res. 6:153-158.

Brown, James K., and M.A. Marsden. 1976. Estimating fuel weights of grasses, forbs, and small woody plants. U.S. Dep. Agr. Forest Res. Note INT-210. Intermountain Forest and Range Exp. Sta., Ogden, Utah. 11 p.

Davis, J. Barry, P.T. Tueller, and A.D. Bruner. 1972. Estimating forage production from shrub ring widths in Hot Creek Valley, Nevada. J. Range Manage. 25:398-402.

Demming, John E., R.E. Burgan, and J.D. Cohen. 1978. The national firedanger rating system. U.S. Dep. Agr. Forest Serv. Tech. Rep. INT-39. Intermoun. Forest and Range Exp. Sta., Ogden, Utah. 67 p.

Evans, Raymond A., and M.B. Jones. 1958. Plant height times ground cover versus clipped samples for estimating forage production. Agron J. 50:504-506.

Grigal, David F., and L.F. Ohmann. 1977. Biomass estimation for some shrubs from northestern Minnesota. U.S. Dep. Agr. Forest Serv. Res. Note NC-226. North Central Forest Exp. Sta., St. Paul, Minn. 3 p.

Ludwig, John A., J.F. Reynolds, and P.D. Whitson. 1975. Size-biomass relationships of several Chihuahuan desert shrubs. Amer. Midl. Natur. 94:451-461.

Lyon, L. Jack. 1968. Estimating twig production of serviceberry from crown volumes. J. Wildl. Manage. 32:115-119.

Ohmann, Lewis F., D.F. Grigal, and R.B. Brander. 1976. Biomass estimation for five shrubs from northeastern Minnesota. U.S. Dep. Agr. Forest Serv. Res. Pap. NC-133. North Central Forest Exp. Sta., St. Paul, Minn. $11 \mathrm{p}$.

Rittenhouse, L.R., and F.A. Sneva. 1977. A technique for estimating Big sagebrush production. J. Range Manage. 30:68-70.

Winward, A.H., and E.W. Tisdale. 1977. Taxonomy of the Artemisia tridentata complex in Idaho. Univ. Idaho Coll. Forestry, Wild., and Range Sci. Bull. No. 19. Forestry, Wildl, and Range Exp. Sta., Moscow, Idaho. $13 \mathrm{p}$.

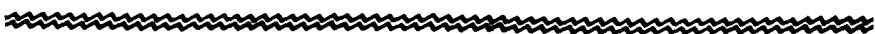

\section{BOTANIST RANGE MANAGER}

To work just outside Bakersfield, California and serve as investigator on endangered species program. We need an advanced degree and experience in practical applied programs to conduct botanical research and studies on habitat restoration for endangered species. If you have the potential to develop the habitat restoration plan, and have additional skills in areas such as:
- Radiation Ecology
- Statistics
- Computers
- Program Development

this is for you! Supervisory capabilities and good communication skills are required. This is a position where you can utilize your talents to develop a significant program. We need someone with 3-5 years field/lab experience and a take-charge attitude! Good salary and excellent benefits accompany this position. If interested, contact:

\section{NEGEG \\ Energy Measurements Group}

\author{
Betty White \\ Personnel Administrator \\ 130 Robin Hill Road \\ Goleta, Ca. 93117
}

U.S. Citizenship Required

An Equal Opportunity Employer 